\title{
The effects of the fungicide captafol on mitosis of Aspergillus nidulans through light and electron microscopic investigations
}

\author{
Andreas Vitoratos ${ }^{1}$, Demosthenis Chachalis ${ }^{2}$, Ilias S Travlos ${ }^{3}$, Dimitrios J Bilalis ${ }^{3 *}$, Basil N Ziogas ${ }^{3}$ \\ ${ }^{1}$ Department of Organic Farming and Food Technology, Technological Educational Institute of lonian Islands, Iosif Momferatou \& Ilia Miniati, \\ 28100, Argostoli Cephalonia, Greece; ${ }^{2}$ Benaki Phytopathological Institute, St. Delta 7, 16451, Kifisia, Athens, Greece; ${ }^{3}$ Agricultural University \\ of Athens, Faculty of Crop Science, 75, lera Odos st., 11855, Athens, Greece
}

\section{A B S T R A C T}

In the present work the genetic activity of the fungicide captafol was studied in a heterozygous diploid strain of Aspergillus (Emericella) nidulans. In vitro fungitoxicity tests of captafol on mycelia growth showed a great increase of the color segregants. Analysis of white and yellow mitotic recombinants suggests that low captafol concentrations $(0.075 \mu \mathrm{g} / \mathrm{ml})$ increase the mitotic crossing-over frequency while non-disjunction was also occurred at high concentrations of $0.15 \mu \mathrm{g} / \mathrm{ml}$. Light and electron microscopic observations of $A$. nidulans cells showed that captafol induces a number of cytological abnormalities in hyphae as well as in cell structures. A destruction of cytoplasmatic membrane, nucleus membrane and other membranes was also observed. At concentrations of the fungicide highly inhibitory to growth (more than 50\%), an abnormal nuclear division was observed which did not follow the typical mitotic function usually observed in Ascomycetes. On the contrary, the formation of an unequal lobe was present, which leads in an unequal distribution of chromosomal material in the sub-nuclei.

Keywords: Aspergillus (Emericella) nidulans; Captafol; Genetic activity; Mitosis

\section{INTRODUCTION}

Captafol and its related analogs captan and folpet are important fungicides which belong to the group of phthalimides (Krieger and Dinoff, 2000). The mode of action of these compounds has been intensively investigated and reviewed in several studies. In particular, their fungitoxicity is considered to be a result of their affinity for the sulfhydryl groups of proteins and cofactors (Lukens, 1971; Siegel, 1971; Corbett, 1974). Captan acts through inhibition of a fungal process of respiration and metabolism through a non-specific thiol reactant (Barreda et al., 2006). CoA and other thiols, such as glutathione and sulfhydryl enzymes, appear to be very important in the mechanism of action of phthalimides, and since the above compounds are functional in many areas of metabolism, the phthalimides obviously affect metabolism in major areas (De Waard and Van Nistelrooy, 1984; Neidert et al., 1985; Fernandez-Cruz et al., 2006). However, several studies have sown that these fungicides and/or their breakdown products may cause mutagenesis (Clarke, 1971; Bridges et al., 1975), induce chromosomal breaks and other important changes (Robens, 1970).

Furthermore, it has already been reported that pthalimides increase the frequency of mitotic segregation, leading to the production of color in diploid strains of Aspergillus nidulans. It has been also shown by Ziogas and Georgopoulos (1987) that most of the induced segregants resulted from mitotic crossing-over observed at low fungicide concentrations, while high concentrations also showed some effects. In addition, Couch and Siegel (1977) suggested that phthalimides exert deleterious effects on the genetic material. This may diminish the ability of histones to stabilize DNA structure and make chromosomes more susceptible to enzyme attack and damages.

The objective of the present study was to evaluate the genetic activity of captafol, focusing in changes in hyphae morphology and in the behavior of chromosomes during

\footnotetext{
*Corresponding author:

Dimitrios J. Bilalis, Agricultural University of Athens, Faculty of Crop Science, 75, lera Odos st., 11855 Athens, Greece.

E-mail: bilalisdimitrios@yahoo.gr. Tel. 00302105294494
} 
nuclear division and also searching for potential alterations in nuclear membrane during the above function, by means of light and electron microscope.

\section{MATERIALS AND METHODS}

\section{Test organism}

The diploid strain of $A$. nidulans which was used produces green conidia and is heterozygous for the recessive genes y and $\mathrm{w}$ responsible for yellow and white conidia, respectively.

In order to measure the frequency of appearance of color recombinants, complete medium (Corbett, 1974) was used. Information on the genotype of the heterozygous diploid strain of $A$. nidulans, which was used, has been given in a previous publication by Robinow and Caten (1969).

\section{Plant protection product}

Phthalimide fungicide captafol was of analytical standard grade and was obtained by Chevron Chemical Co. Ethanol solutions of the compound were added to growth media to give the concentrations of 0.075 and $0.15 \mathrm{mg} / \mathrm{ml}$ and the experiment was conducted under a completed randomized design with three replications. The solvent concentration in $\mathrm{CM}$, which never exceeded $1 \%$ (v/v), had no effect on growth and mitosis of $A$. nidulans.

\section{Light microscopy}

In the present study, the methods described by Robinow and Caten (1979) and Davidse (1973) were used to observe the effects of captafol. In particular, conidia from the $\operatorname{diploid} A$. nidulans strain were spread on sheets of sterilized cellophane, on the surface of agar medium with or without fungicide, and incubated at $37^{\circ} \mathrm{C}$. After $6 \mathrm{hr}$ of incubation, sheet fractions were removed at $1 \mathrm{hr}$ intervals and fixed for 10 min in modified Helly's solution (1): $5 \%$ (w/v) mercuric chloride, $3 \%(\mathrm{w} / \mathrm{v})$ potassium dichromate in water with $6 \%$ $(\mathrm{v} / \mathrm{v})$ of a $3 \%$ formaldehyde solution. After fixation, the sheets were washed with $70 \%$ (v/v) ethanol and hydrolyzed in $1 \mathrm{~N} \mathrm{HCl}$ for $12 \mathrm{~min}$ at $60^{\circ} \mathrm{C}$, washed with distilled water and stained for $1 \mathrm{hr}$ in Giemsa (2ml Giemsa's Losung, Merk, in $100 \mathrm{ml} 0.05 \mathrm{M}$ phosphate buffer, $\mathrm{pH}$ 7.0). Germ tubes and young mycelia were then examined with a Zeiss research photomicroscope.

\section{Electron microscopy}

Suspensions of conidia of the diploid strain in complete liquid medium with and without captafol were shaken for $8 \mathrm{hr}$ and then centrifuged. The pellet was fixed in 1\% $\mathrm{KMnO}_{4}$ for $10 \mathrm{~min}$ at $0-4^{\circ} \mathrm{C}$. After several dehydrations in a graded acetone series, the material was embedded in an Epon-Araldite mixture. Sections, approximately 700-900 thick, were made with glass knives using a Reichert $\mathrm{OM} \mathrm{U}_{3}$ ultramicrotome and placed on grids coated with formvar and carbon. Sections stained with uranyl acetate and lead citrate were examined with a Hitachi HU-12A transmission electron microscope.

\section{RESULTS AND DISCUSSION}

Untreated conidia of the diploid $A$. nidulans strain produced normal, long, unbranched germ tubes. The chromatin of interphase nuclei had a ring shape and was located around the less densely stained nucleolus (Fig. 1). Our results confirm the chromatin clustering that was observed at prophase. Progressively, chromatin was transformed to two parallel rows and then migrated toward opposite poles. It has to be noted that the distance between the newly formed daughter nuclei had an increasing trend during early telophase, but the nuclei were still connected with the spindle. The The beginning of mitosis was accompanied by the appearance of a pair of granules (Fig. 1), probably the spindle pole bodies (SPBs).

Captafol was tested in concentrations 0.075 and $0.15 \mu \mathrm{g} / \mathrm{ml}$. The above two concentrations were selected because of the observation made by Ziogas and Georgopoulos (1987) on the different mechanism of genetic activity on diploid strain of A. nidulans. At low captafol concentration $(0.075 \mu \mathrm{g} / \mathrm{ml})$ most of the induced segregants resulted from mitotic crossing-over but chromosome non-disjunction or loss was also caused at high concentration of the fungicide $(0.15 \mu \mathrm{g} / \mathrm{ml})$.

Conidia of $A$. nidulans germinating in the presence of captafol $(0.075 \mu \mathrm{g} / \mathrm{ml})$ have not shown any serious morphological alterations. In many cases they were observed nuclei at mesophase with distinct nucleoli which were surrounded by dense chromatin. Nuclei distribution was similar to that observed in control (untreated) cells. The typical stages of nuclear division (i.e. prophase, metaphase, anaphase and telophase) were present in the same frequency as in the case of the untreated conidia of the diploid $A$. nidulans.

Conidia germinating in the presence of captafol at $0.15 \mu \mathrm{g} / \mathrm{ml}$, showed significant morphological and chromosomal abnormalities in the diploid $A$. nidulans. In most cases, the terminal parts of hyphae appeared a slight swelling, while chromosomes seemed to elongate in long threads with parallel arrangement, perpendicular to the lengthwise axis of hypha (Fig. 2). Moreover, abnormal configurations of chromatin with dissimilar condensation appeared. The pair of granules in the periphery of the nucleus and the normal stages of mitosis observed in untreated hyphae was not found in germ tubes produced in the presence of captafol at $0.15 \mu \mathrm{g} / \mathrm{ml}$. 


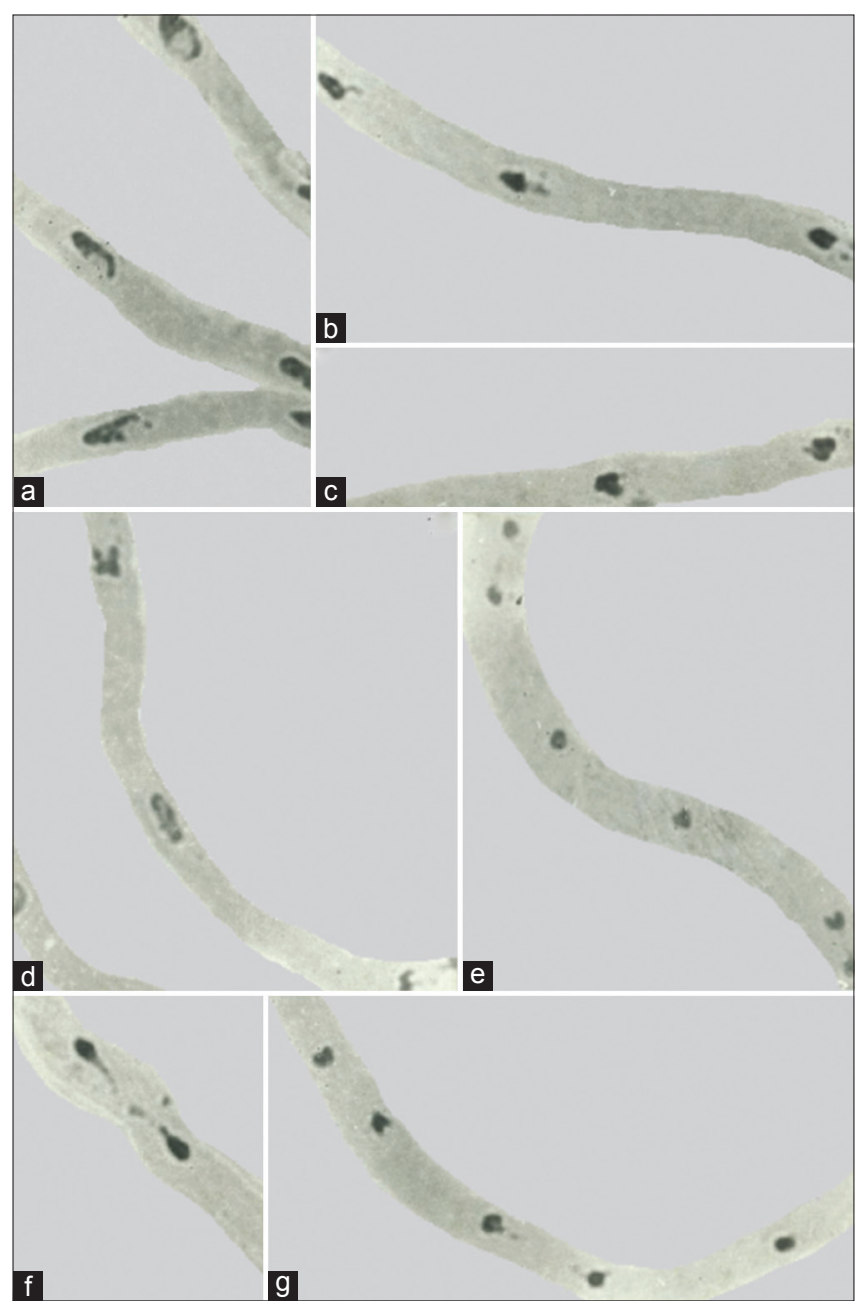

Fig 1. Light micrograps of $A$. nidulans, taken $4 \mathrm{hr}$ after the beginning of germination. Untreated young hyphae with nuclei are shown at: (a) mesophase, (b, c) prophase, (d) metaphase, (e) anaphase and $(f, g)$ telophase. All figures $\times 1750$.

Several abnormalities were observed in the conidia of A. nidulans with the presence of captafol (at 0.075 and $0.15 \mu \mathrm{g} / \mathrm{ml}$ ). An increase in the number of mitochondria and in the structures of endoplasmic reticulum especially at $0.15 \mu \mathrm{g} / \mathrm{ml}$ concentration of captafol was revealed. It seems that this fungicide induces a rapid destruction of the mitochondrial membranes and in membranes of the endoplasmatic reticulum. These damages were more intense as the concentration of the fungicide increased and in some cases incomplete degeneration of these cellular structures was also observed.

In the presence of captafol at $0.075 \mu \mathrm{g} / \mathrm{ml}$ nuclear membrane shows gaps with size depending on fungicide appearance time. In some cases, a complete degeneration of the nuclear membrane was also observed. The gaps on the nuclear membrane probably result to the loss of nuclear material in the protoplasma. The nuclear division seems to follow the typical way which was also observed
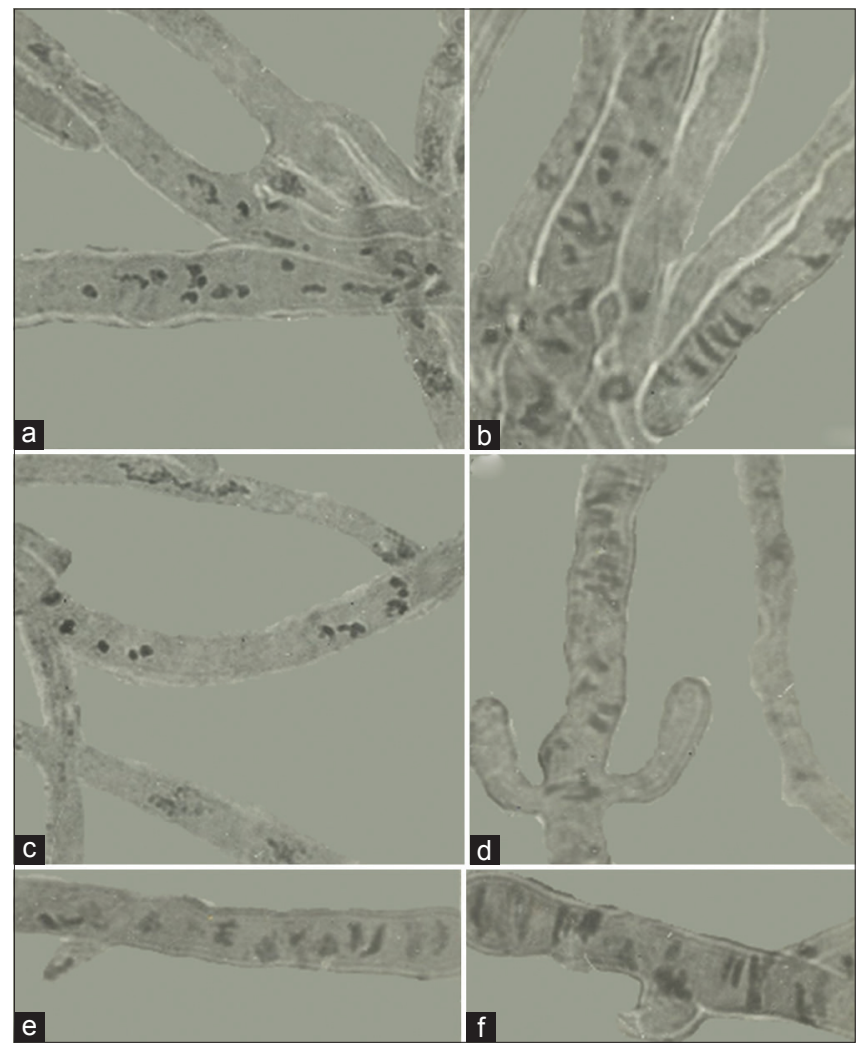

Fig 2. Light micrograps of $A$. nidulans, taken $4 \mathrm{hr}$ after the beginning of germination. Young hyphae produced in the presence of captafol at $0.15 \mu \mathrm{g} / \mathrm{ml}$. The abnormal swelling and branching of the hyphae and irregular dense masses of chromatin are also shown. All figures $\times 1750$.

in untreated cells. It is based on elongation of the nucleus and separation into two lobes which pinch off giving the two daughter nuclei (Fig. 3).

In the presence of captafol at $0.15 \mu \mathrm{g} / \mathrm{ml}$ a significant effect on the process of nuclear division was revealed. In this case and instead of the normal procedure, nucleus developed a lobe with dissimilar electron density (Fig. 4 and Table 1).

Captafol's fungitoxicity is well-known as a result of its attraction from the sulfhydryl groups of proteins (Kumar et al., 1975; Ritcey et al., 1987). However, such an unspecializated action is responsible for inhibition in many areas of metabolism and determine the toxicity of this fungicide (Corbett, 1974; Rahden-Staron et al., 1994; Rahden-Staron, 2002).

Previous reports suggested that captan and folpet, two fungicides relative to captafol, increased sectoring in a heterozygous diploid strain of $A$. nidulans (Richmond and Somers, 1966; Ziogas and Georgopoulos, 1987). Furthermore, captan has been reported to have mutagenic effects on some bacteria (Davidse, 1973; De Waard and Van Nistelrooy, 1984b). 


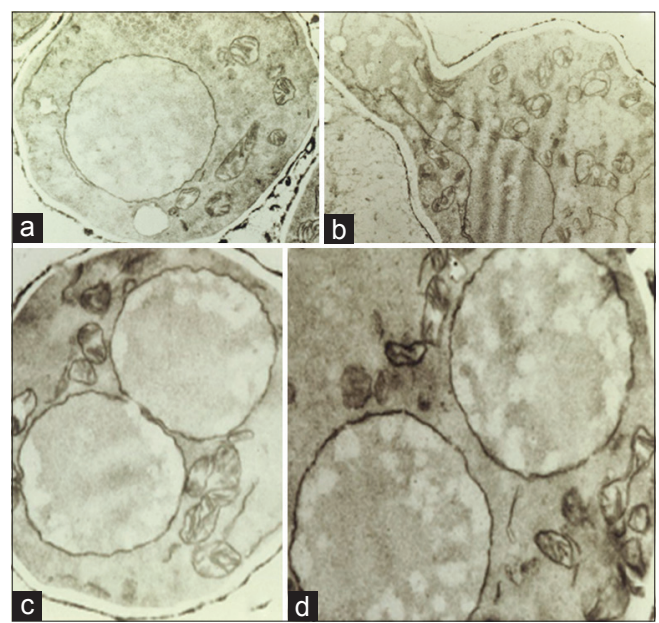

Fig 3: Thin sections of untreated conidia of $A$. nidulans. a $\times 14.224$; b $\times 17.780 ; c, d \times 10.668$.

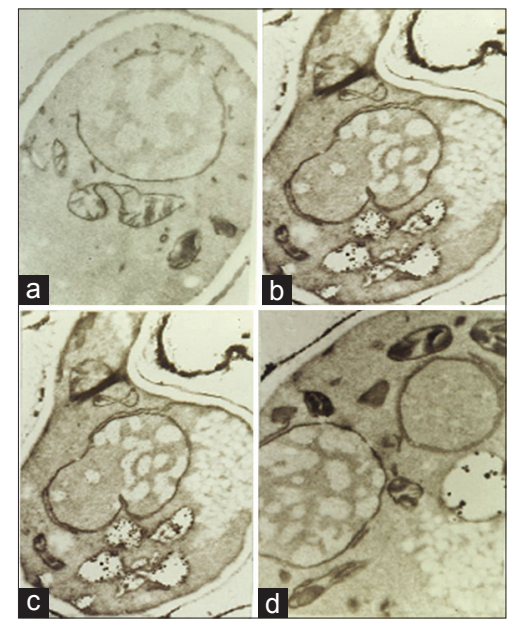

Fig 4. Conidia of $A$. nidulans after treatment with captafol at $0.15 \mu \mathrm{g} / \mathrm{ml}$. The gaps of the nuclear membrane and the striking effect on the process of nuclear division are also shown. Instead of the normal procedure, nucleus develops a lobe with dissimilar electron density. All figures $\times 10.668$.

Table 1: Effects of captafol on colony formation, number of analyzed segregants and mitotic segregants in 100 colonies of A. nidulans

\begin{tabular}{lcccc}
\hline $\begin{array}{l}\text { Captafol } \\
(\mu \mathrm{g} / \mathrm{ml})\end{array}$ & $\begin{array}{c}\text { Inhibition } \\
\text { of colony } \\
\text { formation }(\%)\end{array}$ & $\begin{array}{c}\text { Number of } \\
\text { analyzed } \\
\text { segregants }\end{array}$ & \multicolumn{2}{c}{$\begin{array}{c}\text { Mitotic segregants } \\
\text { in } 100 \text { colonies }\end{array}$} \\
\hline 0.00 & $0 \mathrm{a}$ & $65 \mathrm{e}$ & $0.3 \mathrm{~g}$ & $0.5 \mathrm{i}$ \\
0.05 & $20 \mathrm{ab}$ & $61 \mathrm{de}$ & $0.5 \mathrm{~g}$ & $14.5 \mathrm{k}$ \\
0.10 & $42 \mathrm{~b}$ & $37 \mathrm{~d}$ & $1.9 \mathrm{~g}$ & $15.4 \mathrm{k}$ \\
0.15 & $58 \mathrm{bc}$ & $79 \mathrm{e}$ & $13.3 \mathrm{~h}$ & $5.8 \mathrm{j}$ \\
0.25 & $80 \mathrm{c}$ & $208 \mathrm{f}$ & $19.3 \mathrm{~h}$ & $4.0 \mathrm{j}$ \\
\hline
\end{tabular}

Different low case letters within each column denote significant differences between the several concentrations (at $p<0.05$ )

At low captafol concentrations, most of the induced segregants resulted from mitotic crossing-over but chromosome nondisjunction or loss was also caused at high concentrations (Neidert et al., 1985; Gordon, 2010). Moreover, cytological observations with light microscope showed that conidia germinating in the presence of captafol $(0.075 \mu \mathrm{g} / \mathrm{ml})$ had not any serious morphological alterations. As previously noted, the typical stages of nuclear division were present in the same frequency as in the case of untreated conidia of the diploid $A$. nidulans. However, a slight swelling at the terminal parts of hyphae was also revealed. Such effects could be attributed to the interference of captafol to membrane bound enzymes with sulfhydryl groups and probably these enzymes participate to cell wall composition.

In the present study, cytological observations with the electron microscope showed that nuclear division followed the typical path which was observed in control cells. After the completion of this function two daughter nuclei with similar electron density were formed. These observations support data of color segregants analysis according to which the above mechanism is responsible for captafol's genetic activity.

It was previously suggested that phthalimide fungicides form a stable product with non-thiole sites of calf thymus histones (Couch and Siegel, 1977; Rawn et al., 2007). This may significantly reduce the ability of histones to stabilise DNA structure and make chromosomes more vulnerable to breaks. Such an action against the chromosomes might also explain chromatid exchanges during mitosis.

\section{CONCLUSIONS}

The present study revealed that in the presence of captafol at a rate of $0.15 \mu \mathrm{g} / \mathrm{ml}$ there were some alterations on nuclear division. By means of the light microscope a noticeable alterations on the structure of the nuclei and mitosis were revealed in the presence of captafol, while abnormal configurations of chromatin also occured. In addition, a striking effect on nuclear division was also found. In particular, nucleus developed a lobe with dissimilar electron density. Since the nuclei were well preserved and the nuclear membrane appeared intact, probably captafol at high concentrations has an interference with the structure or the functions of the spindle or the nuclear membrane. Further studies are required in order to confirm the results of the present study and evaluate similar effects in other cases.

\section{Author's Contributions}

The contribution of all authors was equal in this study.

\section{REFERENCES}

Barreda, M., F. J. López, M. Villarroya, J. Beltran, J. M. Garcia-Baudín and F. Hernández. 2006. Residue determination of captan and folpet in vegetable samples by gas chromatography/negative 
chemical ionizationmass spectrometry. J. AOAC. Int. 89(4): 1080-1087.

Bridges, B. A., R. P. Mottershead and C. Collella. 1975. Induction of forward mutations to colicin E2 resistance in repair deficient strains of Escherichia coli: Experiments with ultraviolet light and captan. Mutat. Res. 32: 3-9.

Clarke, C. H. 1971. The mutagenic specificities of pentachloronitrobenzene and captan, two environmental mutagens. Mutat. Res. 11: 247-253.

Corbett, J. R. 1974. The Biochemical Mode of Action of Pesticides. Academic Press, London/New York, Pp. 258-263.

Couch, R. C. and M. R. Siegel. 1977. Interaction of captan and folpet with mammalian DNA and histones. Pestic. Biochem. Physiol. 7: 531-537.

Davidse, L. C. 1973. Antimitotic activity of methyl benzimidazole-2ylcarbamate (MBC) in Aspergillus nidulans. Pestic. Biochem. Physiol. 3: 317-325.

De Waard, M. A. and J. G. M. Van Nistelrooy. 1984. Effects of phthalimide fungicides on the accumulation of fenarimol by Aspergillus nidulans. Pest Sci. 5: 55-59.

Fernández-Cruz, M. L., M. Barreda, M. Villarroya, A. Peruga, S. Llanos and J. M. García-Baudín. 2006. Captan and fenitrothion dissipation min field-treated cauliflowers and effect of household processing. Pest Manag. Sci. 62(7): 637-645.

Gordon, E. B. 2010. Captan and folpet. In: Krieger, R., editor. Handbook of Pesticide Toxicology. Elsevier, New York, Pp. 1915-1949.

Krieger, R. I. and T. M. Dinoff. 2000. Captan fungicide exposures of strawberry harvesters using THPI as a urinary biomarker. Arch. Environ. Contam. Toxicol. 38(3): 398-403.

Kumar, S. S., H. C. Sikka, J. Saxena and G. Sweing. 1975. Membrane damage in human erythrocytes caused by captan and captafol. Pestic. Biochem. Physiol. 5: 338-352.
Lukens, R. J. 1971. Chemistry of Fungicidal Action. Springer-Verlag New York.

Neidert, K., L. V. Epps and W. Welch. 1985. Inhibition of Penicillium duponti carboxylesterase by the fungicides captan and folpet. Pestic. Biochem. Physiol. 23: 221-226.

Rahden-Staron, I. 2002. The inhibitory effect of the fungicides captan and captafol on eukaryotic topoisomerases in vitro and lack of recombinagenic activity in the wing spot test of Drosophila melanogaster. Mutat. Res. Genet. Toxicol. Environ. Mutagen. 518: 205-213

Rahden-Staron, I., M. Szumilo and P. Ziemkiewicz. 1994. The effects of captan and captafol on different bacterial strains and on c-mitosis in V79 Chinese hamster fibroplasts. Acta Biochim. Pol. 41: 45-55.

Rawn, D. F. K., S. C. Quade, J. B. Shields, G. Conca, W. F. Sun, G. M. A. Lacroix, M. Smith, A. Fouquet and A. Bélanger. 2007. Variability in captan residues in apples from Canadian orchard. Food Addit Contam. 24(2): 149-155.

Ritcey, G., R. Frank, F. L. McEwen and H. E. Braun. 1987. Captan residues on strawberries and estimates of exposure to pickers. Bullet. Environ. Contamin. Toxicol. 38(5): 840-846.

Robens, J. F. 1970. Teratogenic activity of several phthalimide derivatives in the golden hamster. Toxicol. Appl. Pharmacol. 16: 24-29.

Robinow, C. F. and C. E. Caten. 1969. Mitosis in Aspergillus nidulans. Cell Sci. 9: 403-409.

Siegel, M. R. 1971. Reactions of the fungicide folpet [N-(trichloromethylthio) phthalimide] with a thiol protein. Pestic. Biochem. Physiol. 1: 225-229.

Ziogas, B. N. and S. G. Georgopoulos. 1987. Genetic effects of phthalimide fungicides on diploid Aspergillus nidulans. Pestic. Sci. 20: 193. 